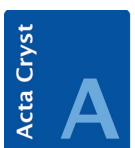

FOUNDATIONS ADVANCES
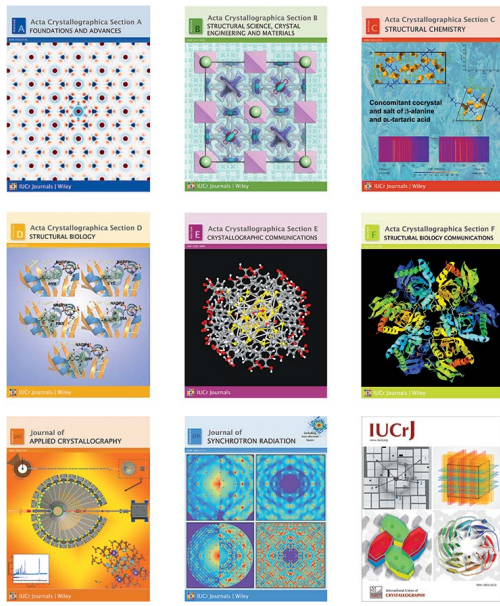

(C) 2019 International Union of Crystallography

\section{Prices of IUCr journals}

\section{Prices for 2020}

The subscription rates as from 1 January 2020 are given in Table 1.

There will be a $5 \%$ discount on the prices of the individual sections for subscribers taking out any of the combined subscriptions.

The reduced-rate (personal) subscriptions are ordinarily only available to members of recognized scientific societies, and applications must be accompanied by an undertaking that the journal is for the personal use of the subscriber and will not be made available to libraries, institutions etc.

Acta Crystallographica Section E and IUCrJ are open access. Authors whose institution has a full subscription to Acta Crystallographica Section $C$ are eligible for a discount on the open-access fee for Acta Crystallographica Section E.

\section{Crystallography Journals Online}

All IUCr journals will be available online in 2020 from Crystallography Journals Online via the following addresses:

Acta Crystallographica Section A: Foundations and Advances, https://journals.iucr.org/a/

Acta Crystallographica Section B: Structural Science, Crystal Engineering and Materials, https://journals.iucr.org/b/

Acta Crystallographica Section C: Structural Chemistry, https://journals.iucr.org/c/

Acta Crystallographica Section D: Structural Biology, https://journals.iucr.org/d/

Acta Crystallographica Section E: Crystallographic Communications, https://journals.iucr.org/e/

Acta Crystallographica Section F: Structural Biology Communications, https://journals.iucr.org/f/

IUCrData, https://iucrdata.iucr.org/x/

IUCrJ, https://journals.iucr.org $/ \mathrm{m} /$

Journal of Applied Crystallography, https://journals.iucr.org/j/

Journal of Synchrotron Radiation, https://journals.iucr.org/s/

A number of services, including tables of contents, e-mail alerting and the provision of supplementary material, remain free of charge to both subscribers and nonsubscribers. In addition, both subscribers and nonsubscribers will retain access to full texts of certain types of article (e.g. CIF Applications, Letters to the Editor, Book Reviews) and to some individual articles of other types.

\section{Licences}

Subscribers will be granted access to IUCr journals in 2020 without a licence. However, subscribers will be asked to read the current Terms and Conditions of Use of Crystallography Journals Online before registering for the service.

\section{Wiley Online Library}

IUCr journals will also be available through Wiley Online Library (https://onlinelibrary. wiley.com/). 
Table 1

Institutional and personal subscription price information for IUCr journals for 2020.

All journals are online only. Prices are in GBP. Euro (European Union) and US dollar prices (The Americas/Rest of the World) are available from Wiley.

\begin{tabular}{|c|c|c|c|c|c|c|}
\hline Journal name & $\begin{array}{l}\text { Volume } \\
\text { in } 2020\end{array}$ & $\begin{array}{l}\text { Number } \\
\text { of issues }\end{array}$ & $\begin{array}{l}\text { Month of } \\
\text { first issue }\end{array}$ & ISSN & $\begin{array}{l}\text { Subscription } \\
\text { type }\end{array}$ & $\begin{array}{l}\text { Price } \\
(\mathrm{GBP})\end{array}$ \\
\hline \multirow{2}{*}{$\begin{array}{l}\text { Acta Crystallographica Section A: } \\
\text { Foundations and Advances }\end{array}$} & \multirow[t]{2}{*}{76} & \multirow[t]{2}{*}{6} & \multirow[t]{2}{*}{ January } & \multirow[t]{2}{*}{$2053-2733$} & Institutional & 780 \\
\hline & & & & & Personal & 170 \\
\hline \multirow{2}{*}{$\begin{array}{l}\text { Acta Crystallographica Section B: } \\
\text { Structural Science, Crystal Engineering } \\
\text { and Materials }\end{array}$} & \multirow[t]{2}{*}{76} & \multirow[t]{2}{*}{6} & \multirow[t]{2}{*}{ February } & \multirow[t]{2}{*}{$2052-5206$} & Institutional & 827 \\
\hline & & & & & Personal & 181 \\
\hline \multirow{2}{*}{$\begin{array}{l}\text { Acta Crystallographica Section C: } \\
\text { Structural Chemistry }\end{array}$} & \multirow[t]{2}{*}{76} & \multirow[t]{2}{*}{12} & \multirow[t]{2}{*}{ January } & \multirow[t]{2}{*}{ 2053-2296 } & Institutional & 2216 \\
\hline & & & & & Personal & 454 \\
\hline \multirow{2}{*}{$\begin{array}{l}\text { Acta Crystallographica Section D: } \\
\text { Structural Biology }\end{array}$} & \multirow[t]{2}{*}{76} & \multirow[t]{2}{*}{12} & \multirow[t]{2}{*}{ January } & \multirow[t]{2}{*}{$2059-7983$} & Institutional & 1323 \\
\hline & & & & & Personal & 285 \\
\hline $\begin{array}{l}\text { Acta Crystallographica Section E: } \\
\text { Crystallographic Communications }\end{array}$ & 76 & 12 & January & $2056-9890$ & Open access & - \\
\hline \multirow{2}{*}{$\begin{array}{l}\text { Acta Crystallographica Section F: } \\
\text { Structural Biology Communications }\end{array}$} & \multirow[t]{2}{*}{76} & \multirow[t]{2}{*}{12} & \multirow[t]{2}{*}{ January } & \multirow[t]{2}{*}{$2053-230 X$} & Institutional & 1233 \\
\hline & & & & & Personal & 239 \\
\hline IUCrData & 5 & 12 & January & 2414-3146 & Open access & - \\
\hline$I U C r J$ & 7 & 6 & January & $2052-2525$ & Open access & - \\
\hline \multirow[t]{2}{*}{ Journal of Applied Crystallography } & \multirow[t]{2}{*}{53} & \multirow[t]{2}{*}{6} & \multirow[t]{2}{*}{ February } & \multirow[t]{2}{*}{$1600-5767$} & Institutional & 851 \\
\hline & & & & & Personal & 181 \\
\hline Journal of Synchrotron Radiation & 27 & 6 & January & $1600-5775$ & Institutional & 1269 \\
\hline & & & & & Personal & 281 \\
\hline Special packages & & & & & & \\
\hline Acta Crystallographica Sections A, & & & January & & Institutional & 3620 \\
\hline$B$ and $C$ & & & & & Personal & 754 \\
\hline Acta Crystallographica Sections A, & & & January & & Institutional & - \\
\hline$B, D$ and $F$ & & & & & Personal & 593 \\
\hline Acta Crystallographica Sections A, & & & January & & Institutional & 4872 \\
\hline$B, C, D$ and $F$ & & & & & Personal & 1019 \\
\hline Acta Crystallographica Sections $B$ & & & January & & Institutional & 2884 \\
\hline and $C$ & & & & & Personal & 597 \\
\hline Journal of Applied Crystallography and & & & January & & Institutional & 2008 \\
\hline Journal of Synchrotron Radiation & & & & & Personal & 436 \\
\hline Full package & & & January & & Institutional & 6869 \\
\hline & & & & & Personal & 1449 \\
\hline
\end{tabular}

\section{Back-issues policy}

Crystallography Journals Online provides electronic editions of the full back catalogue of IUCr journals (from 1948 to date). This back-issue archive consists of approximately 145000 articles and 460000 pages.

Subscribers holding a current subscription to a particular journal will have access to all back issues of that journal via Crystallography Journals Online. Individual articles from the back-issue archive will also be available to nonsubscribers on payment of a fee for each individual article.

\section{Archiving}

The IUCr has prepared a statement on its long-term archiving policy. This is available from https://journals.iucr.org/services/ subscriberservices.html.

\section{Orders}

Information concerning ordering of Acta Crystallographica, Journal of Applied Crystallography and Journal of Synchrotron Radiation may be be found at http://olabout.wiley.com/ WileyCDA/Section/id-406100.html. 